Athens Journal of Business \& Economics -

Volume 8, Issue 1, January 2022 -Pages 43-64

\title{
Factors that Influence FinTech Adoption in South Africa: A Study of Consumer Behaviour towards Branchless Mobile Banking
}

\author{
By Barbara Jeanne Slazus ${ }^{*} \&$ Geoffrey Bick ${ }^{ \pm}$
}

\begin{abstract}
The widespread use of mobile phones and growth in internet penetration has created a unique opportunity to increase access to financial services. Financial Technology (FinTech) companies and mobile banking (m-banking) empower customers to use digital platforms to utilise financial services without the physical access requirements of traditional banking. This has led to the rise of FinTech firms that are disrupting traditional industry standards by servicing consumers through a range of digital channels and mobile devices. A new completely branchless bank, Bank Zero, is set to launch in South Africa in 2020 to exploit these opportunities. This consumer behavioural study focuses on analysing FinTech adoption in the South African market. An adapted mixedmethod approach was used to identify the enabling and inhibiting factors that motivate consumers to adopt or reject m-banking. Qualitative research was initially conducted via in-depth interviews with 7 respondents. The most salient factors identified in the literature review were tested, and the results were used to develop a quantitative, online questionnaire. A convenience sample of 217 valid responses was collected, and the data was analysed using exploratory factor analysis (EFA). The EFA identified 6 influencing factors: four enabling and two inhibiting factors. The enabling factors that positively influenced FinTech adoption were: Utility, Socio-Economic Influencers, Mobile Device Trust and Youth. The two inhibiting factors were: Perceived Risks and Associated Costs. Interestingly, $74 \%$ of the 217 respondents indicated that they would join a completely branchless bank, using only their mobile phones and the internet to access banking services, showing a high propensity to branchless, m-banking. Finally, the Enhancement Criteria Model based on insights gained from the research findings, is proposed. This model provides recommendation criteria for existing and new FinTech providers who are looking to improve their business models.
\end{abstract}

JEL Codes: D18, G40

Keywords: FinTech, mobile banking, m-banking, branchless banking, consumer behaviour, South Africa

\section{Introduction}

The widespread use of mobile phones and growth in internet penetration have created a unique opportunity to increase access to financial resources and services (Bertha Centre 2016, EY 2016). Unlike traditional banking, which limits customers

\footnotetext{
*Researcher, University of Cape Town, South Africa.

${ }^{ \pm}$Professor, University of Cape Town, South Africa.
} 
to physical branch visits or costly telephonic account services, Financial Technology (FinTech) and mobile banking (m-banking) empower customers to use digitised platforms to access financial services at any time, from any place (Kim et al. 2009, Pandiya and Gupta 2015, Shaikh and Karjaluoto 2014).

The penetration of mobile phones into the South African market is substantial: it is estimated that there were 38 million unique mobile users in South Africa in 2018 , giving a $67 \%$ penetration rate, which continues to grow and outperform the continent's average (Kemp 2018). Similarly, internet penetration is $54 \%$, with 30.81 million South Africans accessing the internet (Kemp 2018), and this continues to grow.

FinTech is broadly defined as "technologically enabled financial innovation that could result in new business models, applications, processes, or products with an associated material effect on financial markets and institutions and the provision of financial services" (Financial Stability Board 2017). FinTech is a compounded term consisting of "finance" and "technology", and denotes the industrial change that results due to the convergence of financial services and Information Technology (IT) (Kim et al. 2016). Given the proliferation of FinTech products and services it is no surprise that there is also a growing number of FinTech users entering the market. It is expected that FinTech adoption will increase to a global average of 52\%, with the highest intended use in developing markets like South Africa, Mexico and Singapore (EY 2016). Industry experts are increasingly forecasting that the future of financial services will involve the forging of meaningful customer relationship (Basel Committee on Banking Supervision 2018). However, although FinTech adoption by digitally active consumers tends to be higher in developing markets, research on mobile commerce suggests potential consumers may not adopt these $\mathrm{m}$-services in spite of availability (Wang et al. 2006).

According to the Global Findex Database (Demirguc-Kunt et al. 2017), growth in FinTech has largely been driven by digital payments, government policies, and a new generation of financial services accessed through mobile phones and the internet. FinTech adoption, by digitally active consumers, tends to be higher in developing markets (EY 2016). The reason for this high adoption rate is twofold: Firstly, FinTech firms are successfully targeting tech-literate consumers thereby minimising budgetary and resource wastage trying to convert nonresponsive audiences. Secondly, FinTech firms are offering products to the financially underserved population of which there are proportionally higher ratios in emerging countries (EY 2016). In South Africa, money transfers and mpayments are driving FinTech adoption (EY 2016).

FinTech firms are earning a reputation for customer-centricity and are characterised by innovative business models and technology to enable, enhance and disrupt financial services (Gomber et al. 2018, Gulamhuseinwala et al. 2015). Dhar and Stein (2017) go further to state that the future of financial services are set to follow retail and travel industries which means that access to financial advisory services could experience the same digital disruption as brick-and-mortar retail stores have experienced over the past decade. 
To ensure commercial success in this growing digital paradigm, all banks and/ or non-bank providers of financial services need to understand and address the factors that drive and hinder consumer adoption of FinTech services and products. Competitive advantage lies in this understanding, especially in light of the new completely branchless bank that is set to launch in South Africa in Q1 2020, namely Bank Zero (Bank Zero 2018). However, academic literature and research on FinTech adoption remains limited, especially in the South African emerging market context.

Consequently, the aim of this study is to determine the enabling and inhibiting factors that influence the adoption of Fintech and mobile banking services in the South African market.

\section{Literature Review}

\section{Consumer Behaviour and Technology Adoption Frameworks}

The Technology Acceptance Model (TAM) is the first framework to hone in on modeling and predicting user acceptance of information systems (Davis et al. 1986). The TAM is highly regarded as a framework that allows for the reasonable depiction of a user's intention to use technology (Akturan and Tezcan 2012). The two direct adoption drivers that impact user attitudes are "perceived usefulness" (PU) and "perceived ease of use" (PEOU) (Davis et al. 1986). The TAM is a prevalent theory in the study of technology acceptance of mobile money in Africa (Chigada and Hirschfelder 2017). Notwithstanding alternative frameworks, the TAM and all its variations is regarded as the most attested model to analyse technology adoption (Adams et al. 2007, Venkatesh et al. 2003, Wentzel et al. 2013). However, Bagozzi (2007) argues that the TAM has a range of limitations especially in its neglect of group, social and cultural aspects of technology adoption.

The Unified Theory of Acceptance and Use of Technology (UTAUT) model was subsequently developed by Venkatesh et al. (2003) to study IT-related adoption in corporate environments. Aptly named, the UTAUT model consolidated eight models, all of which are focused on explaining information systems usage behaviour (Venkatesh et al. 2003). These models include Theory of Reasoned Action (TRA), Technology Acceptance Model (TAM), Motivational Model (MM), Theory of Planned Behaviour (TPB), Model Combining the Technology Acceptance Model and Theory of Planned Behaviour (C-TAM-TPB), Model of PC Utilisation (MPCU), and Innovation Diffusion Theory (IDT).

The UTAUT model is illustrated in Figure 1. Gangwal and Bansal (2016) highlight Venkatesh et al.'s (2003) construct as follows:

i. Performance expectancy is where the user believes that using the system will help him/her to attain gains in job performance.

ii. Effort expectancy is the degree of ease associated with the use of the system. 
iii. Social influence relates to how the individual perceives that important others believe he/she should use the new system.

iv. Facilitating conditions relate to the degree to which an individual believes that an organisational and technical infrastructure exists to support use of the system.

Figure 1. Unified Theory of Acceptance and Use of technology Model (UTAUT)

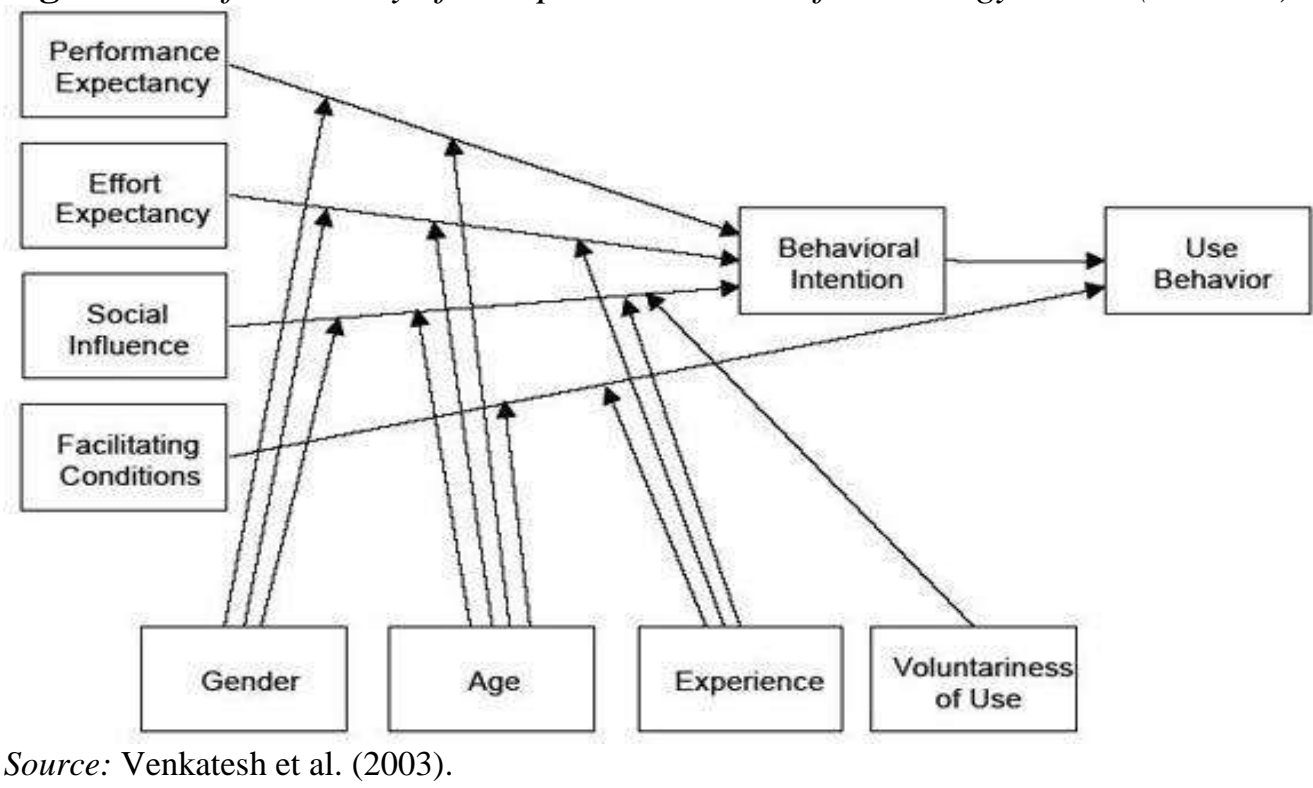

A further applicable model explaining technology adoption is the Diffusion of Innovation. Rogers (2005, p. 5) defines diffusion as "the process by which an innovation is communicated through certain channels over time among the members of a social system". The successful adoption of the innovation relies heavily on taking a "client-oriented" approach in communicating the benefits of the innovation to potential adopters (Gomber et al. 2018, Rogers 2005). Innovation is regarded as an idea, practice or object that is perceived as new by an individual (Rogers 2005), and this study focuses on FinTech platforms, products and services as a stellar example of $21^{\text {st }}$ century innovation.

Rogers (2005) argues that all social systems can be segmented into the following five distinct groups: Brave pioneers, Early adopters, Early majority, Late majority, and Laggards. According to Ernst \& Young's Fintech Adoption Index (EY 2016), South Africa is regarded as an "early majority" FinTech market with a $35 \%$ adoption rate, $2 \%$ above the global average of $33 \%$.

\section{Factors that Enable Consumer Adoption of FinTech}

\section{Perceived Usefulness (PU)}

Perceived Usefulness (PU) is the extent to which an individual believes that he/she will benefit from using technology, or in this case FinTech and related mbanking services. It is fair to state that individuals firstly determine the consequences of their behaviour and then make a choice based on PU (Kim et al. 
2009). The popular saying "build it and they will come" is an excellent example of the absence of PU and customer-centricity. It could be argued that customers' growing need for personalisation and bespoke services (Dapp 2014) are a contributing element to PU.

Of all factors identified in the reviewed literature, PU was found to be the single most cited factor that enables FinTech adoption. It has a significant effect on attitudes toward using FinTech (Chuang et al. 2016, Wentzel et al. 2013), mbanking (Ismail and Masinge 2011, Pandiya and Gupta 2015, Singh and Srivastava 2018) and m-payment systems (Kim et al. 2016).

$\underline{\text { Trust }}$

Trust and consumer confidence in the security of transactions remain key components to why customers entrust institutions with their finances (Dapp 2014, Wentzel et al. 2013). Based on research done by Dapp (2014) and Zhou (2011), FinTech companies that are able to offer clients lasting and credible data security assurance will obtain the biggest growth and revenue opportunities. Due to the high levels of security risks and relative low switching cost, it is crucial to build initial user trust in order to foster m-banking adoption (Singh and Srivastava 2018, Zhou 2011).

Trust, and its related constructs, was found to be the second most cited enabling factor. It was prevalent in research regarding Internet banking (Akhlaq and Ahmed 2013, Pikkarainen et al. 2004), m-banking (Baptista and Oliveira 2015, Hanafizadeh et al. 2014, Ismail and Masinge 2011, Kim et al. 2009, Maduku 2017, Priya et al. 2018, Singh and Srivastava 2018), m-payments (Dastan and Gurler 2016, Kim et al. 2016) and FinTech adoption (Dapp 2014, EY 2016).

\section{Perceived Ease of Use (PEOU)}

The TAM, and its various derivatives, postulate that PEOU and PU work in conjunction for the when it comes to technology adoption. Davis (1985) refers to PEOU as the degree to which an individual believes that using the system will be free of effort. Mobile or FinTech services that are easy to use will be less threatening to individual customers and in turn be perceived as less complex to use (Davis 1985, Priya et al. 2018, Venkatesh et al. 2003). PEOU enables users to adopt hassle-free technology of $\mathrm{m}$-banking and its services in everyday use (Priya et al. 2018).

The literature reviewed found that PEOU has a significant effect on attitudes toward using FinTech (Chuang et al. 2016, Wentzel et al. 2013) and m-banking (Pandiya and Gupta 2015, Singh and Srivastava 2018). Studies show that customers will be more likely to adopt m-banking if they find it easy to use and understand (Pandiya and Gupta 2015).

\section{Self-Efficacy}

Self-efficacy is a construct that describes consumers' perceived confidence regarding the use of technological innovations (Koksal 2016). In the context of mbanking and FinTech, self-efficacy translates into customers' belief that the required knowledge, skill, or ability to operate this new service results in a higher 
chance of attempting to use the service. Past studies have shown a causal link between self-efficacy and m-banking adoption (Alalwan et al. 2015, Koksal 2016, Lee et al. 2003, Maduku 2017, Makanyeza 2017).

\section{Economic Benefit}

Rogers' (2005) Innovation Diffusion Theory (IDT) introduces "relative advantage" as a major influencing factor in consumers' adoption of technology. Karjaluoto et al. (2002) and Maduku (2017) highlight the cost saving factor of mbanking to be highly revolutionary and advantageous from a consumer perspective. Offering previously paid-for services free of charge or at significantly cheaper prices is the reason why many FinTech providers are regarded as industry disrupters (EY 2016).

\section{Social Influence}

Ernst \& Young's FinTech Adoption Index (EY 2016) highlights the impact that peer-endorsement and positive 'word of mouth' referrals have on encouraging potential customers to adopt FinTech services. Social constructs, specifically social influence, have therefore become an important addition to the TAM to better enable the understanding of adoption (Wentzel et al. 2013). Prior studies of m-banking adoption have also shown a relationship between social influence and intention to use m-banking (Bankole and Cloete 2011, Chitungo and Munongo 2013, Maduku 2017, Makanyeza 2017, Püschel et al. 2010) and FinTech (Wentzel et al. 2013).

\section{Enjoyment, Innovation and Novelty}

In contrast with PU, which is regarded as an extrinsic motivation, perceived enjoyment (PE) is seen as an intrinsic motivation to use information systems (Venkatesh et al. 2003). The aspect of fun was less prevalent in FinTech literature reviewed, yet a number of studies have noticed that PE significantly affects intentions to use m-banking and internet banking (Akhlaq and Ahmed 2013, Alalwan et al. 2015, Lee et al. 2003, Pikkarainen et al. 2004).

This leads us to Proposition 1: The enabling factors for the adoption of FinTech in the South African market are:

- Perceived Usefulness

- Perceived Ease of Use

- Trust

- Self-efficacy

- Economic benefit

- Social influence

- Enjoyment/Innovation / Rarity 


\section{Factors that Inhibit Consumer Adoption of FinTech}

\section{Perceived Risk}

In the context of the FinTech industry, both real and perceived risk is central to the adoption and usage process (Chigada and Hirschfelder 2017, EY 2016). Dapp (2014) emphasises the rise of cybercrime and the increasing number of data misuse cases in the Deutsche Bank's FinTech Report; an increasing number of customers are displaying a greater vigilance when using digital channels to access financial service. Identity theft, phishing, hacking, malware, data breaches and SIM swaps are commonly seen in FinTech environments on the African continent. Due to the high levels of security risk and relative low switching cost, it is crucial to build initial user trust in order to foster m-banking adoption (Singh and Srivastava 2018, Zhou 2011).

\section{$\underline{\text { Perceived Cost of Use }}$}

Ismail and Masinge (2011, p.11) define perceived cost as "the extent to which a person believes that using m-banking will cost money". M-banking costs can include transactional cost in the form of bank charges, mobile network charges for sending communication traffic in the form of data or SMSs, and mobile device costs e.g. buying a mobile device be it a smart phone or basic feature phone (Ismail and Masinge 2011). Cruz et al.'s (2010) research in Brazil and Hanafizadeh et al.'s (2014) research in Iran found that perception of cost is one of the main reasons behind the reluctance to use $\mathrm{m}$-banking in these developing economies. Pandiya and Gupta (2015) also mention that perceived cost is an important factor in $\mathrm{m}$ banking in India.

This leads us to Proposition 2: The inhibiting factors for the adoption of FinTech in the South African market are:

- Perceived Risk

- Perceived Cost of Use

\section{Methodology}

The research methodology utilised was an adapted mixed method approach. The qualitative phase collected data from a purposive sample of 7 respondents through telephonic and skype interviews, using a semi-structured interview schedule. The purpose of this phase was to validate the FinTech adoption factors identified during the literature review, to identify any further insights through thematic analysis of the data, and to develop the questionnaire for the quantitative phase.

In the quantitative phase, the structured questionnaire included six demographic questions, nine behavioural questions, and 24 statements using a five-point Likert rating scale, ranging from strongly agree (rating 1) to strongly disagree (rating 5), and two open-ended questions to explore further enabling and 
inhibiting factors. This questionnaire was pilot tested on five respondents to identify any misinterpretations. The population included all mobile phone/ smartphone owners who have a bank account. The sampling method used was a convenience sampling with snowballing (Bryman and Bell 2011). The questionnaire was administered using an online survey platform "Google Survey", and allowed a link to be generated and circulated via various online and social media channels, including email, Facebook, WhatsApp and LinkedIn; 217 completed responses were obtained for data analysis.

Data was analysed using exploratory factor analysis (EFA), with IBM SPSS statistics software, to identify hidden constructs and the underlying factor structure of a set of variables that are not always apparent from direct analysis (Zikmund et al. 2012). Orthogonal varimax rotation was used to optimise the factors (Pett et al. 2003). The relevant factors were determined using Eigenvalues $>1$, cumulative percentage explained by factors exceeding $60 \%$, and a significant decline in the scree plot. Validity was ensured through pilot testing of the questionnaire, and by including both FinTech adopters and FinTech rejecters in the pool, although the results cannot be generalised due to the sampling method. Reliability was ensured through the large sample size, the use of Kaiser-Meyer-Olkin (KMO) measure of sampling adequacy of $0.839(>0.8)$, Bartlett's test of sphericity as significant at 0.000 (Leung et al. 2010, Pett et al. 2003), and a Cronbach Alpha test of 0.715, which is greater than the requirement of 0.7 for reliability of the questionnaire (Cronbach 1951).

\section{Results - Qualitative Phase}

The convenience sample of seven participants was both frequent users and early adopters of m-banking, and confirmed the following factors as given in Table 1.

The enabling factor Enjoyment/Innovation/Rarity was not felt to be applicable, respondents mentioned that "The Fun factor is not something I think of when doing banking, I don't play around on my app, I go there to do something specific and then I log off."

Two newly identified inhibiting factors were:

- Age: respondents felt that the older generation would be hesitant

- Internet Access: this could be a major obstacle in rural areas with poor internet connection.

The ten factors identified were then used to develop the quantitative research instrument. 
Table 1. Confirmed Influencing Factors - Qualitative Study

\begin{tabular}{|c|c|}
\hline Enabling Factors & Respondent Comments \\
\hline $\begin{array}{l}\text { Perceived } \\
\text { Usefulness (PU) }\end{array}$ & $\begin{array}{l}\text { "When I think of mobile banking I immediately think of } \\
\text { convenience, because I can access it } 24 / 7 \text { from my phone or } \\
\text { iPad." }\end{array}$ \\
\hline $\begin{array}{l}\text { Perceived Ease of } \\
\text { Use (PEOU) }\end{array}$ & $\begin{array}{l}\text { "Fingerprint authentication on my iPhone is much easier and } \\
\text { quicker than using a password on my laptop." }\end{array}$ \\
\hline Trust & $\begin{array}{l}\text { "It makes me feel comfortable to use the app because they have } \\
\text { security measures in place." }\end{array}$ \\
\hline Self-efficacy & $\begin{array}{l}\text { "Because I was already using internet banking, I saw it [m- } \\
\text { banking] as an extension of what I was already doing on my } \\
\text { PC" }\end{array}$ \\
\hline Economic Benefit & $\begin{array}{l}\text { "It was cheaper for me to use m-banking, especially through } \\
\text { the app, and that's why I switched over from traditional } \\
\text { banking methods." }\end{array}$ \\
\hline Social Influence & $\begin{array}{l}\text { "Definitely, word-of-mouth works. The more people use it [m- } \\
\text { banking], the higher the likelihood of more people trying it." }\end{array}$ \\
\hline Inhibiting Factors & Respondent Comments \\
\hline Perceived Risk & $\begin{array}{l}\text { "People want to be able to speak to a human, they don't trust a } \\
\text { completely digitised experience." }\end{array}$ \\
\hline $\begin{array}{l}\text { Perceived Cost of } \\
\text { Use (PCOU) }\end{array}$ & $\begin{array}{l}\text { "Cost of data is a stumbling block and can inhibit people from } \\
\text { using m-banking because it costs them money." }\end{array}$ \\
\hline
\end{tabular}

\section{Results - Quantitative Phase}

\section{Respondent Profile}

The demographic profile of the respondents revealed a reasonable spread: $55 \%$ were female; the majority $(51 \%)$ were in the $26-35$ year age group, followed by $25 \%$ in the $36-45$ year age group; and $93 \%$ had a tertiary education, indicating a fairly educated segment.

In terms of the behavioural profile, $97 \%$ indicated having a smartphone; $94 \%$ use their mobile phones on a daily basis to access the internet; the majority (91\%) make use of m-banking (only $9 \%$ did not), and of this majority, $25 \%$ use it daily and $50 \%$ use it weekly; and $90 \%$ use a banking app. The most frequently performed m-banking tasks were: account balance checks (95\%), bill payments $(86 \%)$, airtime/data/electricity purchases $(83 \%)$, and bank statement requests (67\%). In addition, a sizeable $74 \%$ of respondents indicated that they would join a completely branchless bank, using only their mobile phone/the internet to access their banking services.

\section{Factors Analysis Results}

Exploratory factor analysis was conducted on the data from the 22 statements in the questionnaire that related to the various attributes of each factor or construct. This revealed that six factors met the eigenvalue criterion of a value greater than 1 ; 
Vol. 8, No. 1 Slazus \& Bick: Factors that Influence FinTech Adoption in South Africa...

this is also confirmed by the scree plot. The results of the factor analysis after varimax rotation are given in Table 2 .

Table 2. Eigenvalues and Variance Explained

\begin{tabular}{|c|c|c|c|c|c|c|}
\hline \multicolumn{7}{|c|}{ Total Variance Explained } \\
\hline \multirow[b]{2}{*}{ Component } & \multicolumn{3}{|c|}{ Initial Eigenvalues } & \multicolumn{3}{|c|}{ Extraction Sums of Squared Loadings } \\
\hline & Total & $\begin{array}{c}\% \text { of } \\
\text { Variance }\end{array}$ & $\begin{array}{c}\text { Cumulative } \\
\%\end{array}$ & Total & $\begin{array}{c}\% \text { of } \\
\text { Variance }\end{array}$ & Cumulative \% \\
\hline 1 & 6.52 & $1 \quad|29.640|$ & 29.640 & 6.521 & 29.640 & 29.640 \\
\hline 2 & 2.87 & 13.064 & 42.704 & 2.874 & 13.064 & 42.704 \\
\hline 3 & 1.63 & 7.418 & 50.122 & 1.632 & 7.418 & 50.122 \\
\hline 4 & 1.37 & 6.249 & 56.371 & 1.375 & 6.249 & 56.371 \\
\hline 5 & 1.24 & 5.640 & 62.012 & 1.241 & 5.640 & 62.012 \\
\hline 6 & 1.07 & 4.891 & 66.903 & 1.076 & 4.891 & 66.903 \\
\hline 7 & 0.90 & 4.102 & 71.005 & & & \\
\hline 8 & 0.84 & 3.818 & 74.823 & & & \\
\hline 9 & 0.71 & 3.268 & 78.091 & & & \\
\hline 10 & 0.61 & 2.810 & 80.900 & & & \\
\hline 11 & 0.60 & 2.726 & 83.626 & & & \\
\hline 12 & 0.54 & 2.460 & 86.086 & & & \\
\hline 13 & 0.51 & 2.318 & 88.404 & & & \\
\hline 14 & 0.48 & 2.217 & 90.621 & & & \\
\hline 15 & 0.42 & 1.941 & 92.562 & & & \\
\hline 16 & 0.37 & 1.706 & 94.268 & & & \\
\hline 17 & 0.33 & 1.503 & 95.772 & & & \\
\hline 18 & 0.28 & 1.286 & 97.058 & & & \\
\hline 19 & 0.20 & 0.923 & 97.980 & & & \\
\hline 20 & 0.17 & 0.795 & 98.776 & & & \\
\hline 21 & 0.14 & 0.654 & 99.429 & & & \\
\hline 22 & 0.12 & 0.571 & 100.000 & & & \\
\hline
\end{tabular}

Factors loadings were produced by means of orthogonal varimax rotation. Rotated factors were then extracted based on variable values - the higher the value, the greater influence the variable has on the factor. Hair et al. (2010) consider values with a reading of 0.5 or greater to be particularly significant. Table 3 below shows the Rotated Component Matrix with the highlighted variables that loaded onto the six newly identified factors. 
Table 3. Factor Loadings after Orthogonal Varimax Rotation

Rotated Component Matrix ${ }^{\mathrm{a}}$

\begin{tabular}{|l|c|c|c|c|c|c|}
\hline & \multicolumn{7}{|c|}{ Component } \\
\cline { 2 - 7 } & $\mathbf{1}$ & $\mathbf{2}$ & $\mathbf{3}$ & $\mathbf{4}$ & $\mathbf{5}$ & $\mathbf{6}$ \\
\hline Improvement (PU1) & 0.858 & 0.042 & -0.108 & -0.128 & 0.181 & 0.054 \\
\hline Specific need (PU2) & 0.854 & 0.101 & -0.059 & -0.092 & 0.160 & -0.030 \\
\hline Time saver (PU3) & 0.870 & 0.017 & -0.096 & -0.046 & 0.150 & 0.061 \\
\hline On-the-go access (PU4) & 0.785 & 0.111 & -0.114 & -0.014 & 0.096 & -0.029 \\
\hline UX functionality (PEOU1) & 0.648 & 0.141 & -0.147 & -0.221 & -0.068 & 0.108 \\
\hline Speed (PEOU2) & 0.786 & 0.096 & -0.059 & -0.119 & 0.015 & 0.081 \\
\hline Finger print authentic (PEOU3) & 0.110 & 0.105 & 0.095 & -0.016 & 0.823 & -0.057 \\
\hline Transaction security (TRUST1) & 0.388 & 0.124 & -0.491 & -0.115 & 0.573 & 0.182 \\
\hline Device security (TRUST2) & 0.363 & 0.103 & -0.481 & -0.210 & 0.590 & 0.186 \\
\hline Digital confidence (SE1) & 0.490 & 0.032 & -0.360 & -0.175 & 0.370 & 0.104 \\
\hline Cost saving (EB1) & 0.267 & 0.751 & 0.031 & -0.039 & 0.114 & -0.020 \\
\hline Loyalty programmes (EB2) & -0.023 & 0.667 & 0.082 & -0.042 & 0.179 & -0.110 \\
\hline Community influencers (SI1) & 0.105 & 0.848 & -0.025 & 0.122 & -0.071 & 0.182 \\
\hline Peer influencers (SI2) & 0.095 & 0.826 & 0.000 & 0.101 & -0.032 & 0.232 \\
\hline Human interaction (RISK1) & -0.198 & 0.099 & 0.628 & 0.353 & -0.022 & 0.104 \\
\hline Bigger transactions (RISK2) & -0.034 & -0.032 & 0.808 & 0.034 & 0.134 & 0.092 \\
\hline Data security (RISK3) & -0.195 & 0.156 & 0.617 & 0.151 & -0.293 & -0.015 \\
\hline Cost of data (PCOU1) & -0.122 & 0.035 & 0.101 & 0.850 & -0.037 & -0.047 \\
\hline Cost of using service (PCOU2) & -0.310 & -0.106 & 0.214 & 0.612 & 0.033 & -0.064 \\
\hline Youth (AGE1) & 0.104 & 0.121 & -0.116 & 0.048 & 0.051 & 0.798 \\
\hline Older generation (AGE2) & 0.035 & 0.056 & 0.236 & -0.129 & 0.000 & 0.753 \\
\hline Network coverage (ACCESS1) & -0.055 & 0.144 & 0.096 & 0.712 & -0.136 & 0.008 \\
\hline
\end{tabular}

Extraction Method: Principal Component Analysis.

Rotation Method: Varimax with Kaiser Normalisation. a. Rotation converged in 8 iterations.

Factor 1 has an eigenvalue of 6.521, and six statements load onto this factor, as given in Table 4. These statements have to do with the convenience and usefulness of m-banking, which is beneficial and something valuable that improves their lives, so this factor is termed "Perceived Utility".

Table 4. Factor 1 loading

\begin{tabular}{|l|l|l|}
\hline \multicolumn{3}{|c|}{ Factor 1: Perceived Utility } \\
\hline PU1 & Improvement & M-banking makes my life simpler and easier. \\
\hline PU2 & Specific need & M-banking fulfils a specific banking need that I have. \\
\hline PU3 & Time saver & I use m-banking because it saves me time. \\
\hline PU4 & On-the-go access & $\begin{array}{l}\text { M-banking gives me the freedom to do banking } \\
\text { whenever I need to. }\end{array}$ \\
\hline PEOU1 & UX functionality & M-banking is easy to use and understand. \\
\hline PEOU2 & Speed & M-banking is quicker than other forms of banking. \\
\hline
\end{tabular}

Factor 2 has an eigenvalue of 2.87, with four statements loading onto this factor that have to do with the economic benefit and social influence, as given in Table 5; this factor is termed "Socio-Economic Influencers". 
Vol. 8, No. 1 Slazus \& Bick: Factors that Influence FinTech Adoption in South Africa...

Table 5. Factor 2 Loading

\begin{tabular}{|l|l|l|}
\hline \multicolumn{3}{|c|}{ Factor 2: Socio-Economic Influencers } \\
\hline EB1 & Cost saving & I use m-banking because it saves me money. \\
\hline EB2 & Loyalty programs & $\begin{array}{l}\text { I use m-banking because my bank rewards me for using } \\
\text { this platform. }\end{array}$ \\
\hline SI1 & $\begin{array}{l}\text { Community } \\
\text { influencers }\end{array}$ & $\begin{array}{l}\text { I use m-banking because reputable people in my } \\
\text { community use m-banking. }\end{array}$ \\
\hline SI2 & Peer influencers & I use m-banking because my family and friends do. \\
\hline
\end{tabular}

Factor 3 has an eigenvalue of 1.63, with the three risk construct variables loading onto this factor, as given in Table 6; this factor is termed "Perceived Risk".

Table 6. Factor 3 Loading

\begin{tabular}{|l|l|l|}
\hline \multicolumn{2}{|c|}{ Factor 3: Perceived Risk } \\
\hline RISK1 & $\begin{array}{l}\text { Human } \\
\text { interaction }\end{array}$ & I prefer to interact with a human when I do my banking. \\
\hline RISK2 & $\begin{array}{l}\text { Bigger } \\
\text { transactions }\end{array}$ & $\begin{array}{l}\text { I prefer to interact with a human when I do big financial } \\
\text { transactions. }\end{array}$ \\
\hline RISK3 & Data security & $\begin{array}{l}\text { There is greater risk of fraud when using m-banking } \\
\text { compared to using other forms of banking. }\end{array}$ \\
\hline
\end{tabular}

Factor 4 has an eigenvalue of 1.38, with three statements loading onto this factor that have to do with direct and indirect costs of m-banking, as given in Table 7; this factor is termed "Associated Costs".

Table 7. Factor 4 Loading

\begin{tabular}{|l|l|l|}
\hline \multicolumn{3}{|c|}{ Factor 4: Associated Costs } \\
\hline PCOU1 & Cost of data & Data costs are keeping me from using m-banking. \\
\hline PCOU2 & Service cost & $\begin{array}{l}\text { M-banking is more expensive than other forms of } \\
\text { banking. }\end{array}$ \\
\hline ACCESS1 1 & $\begin{array}{l}\text { Network } \\
\text { coverage }\end{array}$ & $\begin{array}{l}\text { Unreliable network coverage keeps me from using } \\
\text { m-banking. }\end{array}$ \\
\hline
\end{tabular}

Factor 5 has an eigenvalue of 1.24, with three statements loading onto this factor, which have to do with user preference and trust factors in m-banking, as given in Table 8; this factor is termed "Mobile Device Trust".

Table 8. Factor 5 Loading

\begin{tabular}{|l|l|l|}
\hline \multicolumn{3}{|c|}{ Factor 5: Mobile Device Trust } \\
\hline PEOU3 & $\begin{array}{l}\text { Finger print } \\
\text { authentication }\end{array}$ & $\begin{array}{l}\text { I prefer using finger print authentication because } \\
\text { it is quicker than typing in a password. }\end{array}$ \\
\hline TRUST1 & $\begin{array}{l}\text { Transaction } \\
\text { security }\end{array}$ & $\begin{array}{l}\text { M-banking is as secure as traditional forms of } \\
\text { banking. }\end{array}$ \\
\hline TRUST2 & Device security & $\begin{array}{l}\text { It is secure to use my mobile phone to do } \\
\text { banking. }\end{array}$ \\
\hline
\end{tabular}

The final factor 6 has an eigenvalue of 1.08 , with two variables loading on to this factor, which both have to do with the perception that m-banking is for the younger generation, as given in Table 9; this factor is termed "Youth". 
Table 9. Factor 6 Loading

\begin{tabular}{|l|l|l|}
\hline \multicolumn{3}{|c|}{ Factor 6: Youth } \\
\hline AGE1 & Youth & $\begin{array}{l}\text { Young people are more likely to use their mobile } \\
\text { devices to do banking. }\end{array}$ \\
\hline AGE2 & Older generation & $\begin{array}{l}\text { Older people are more reluctant to use their mobile } \\
\text { devices to do banking. }\end{array}$ \\
\hline
\end{tabular}

\section{Additional Findings}

The two final open-ended questions in the survey enabled respondents to mention any additional influencing factors pertaining to FinTech adoption. The additional enabling factors identified were: Traceability (included in Factor 1), Travel convenience (also in Factor 1), and Facial recognition (part of Factor 5).

The additional inhibiting factors identified were: Downtime (part of Factor 4), Lack of awareness of m-banking, Platform limitations (certain functionalities not available on m-banking), and Device limitations (size of the font and buttons on a phone). While some of these are difficult for banks to address, certainly the lack of awareness points to an opportunity to educate the consumer, especially non-users of m-banking.

\section{Discussion and Conclusion}

\section{Discussion Pertaining to Proposition 1}

The objective of this study was to identify the factors that influence consumer adoption of FinTech services in the South African market. The results of this study compared to the factors identified by prior research are given in Table 10.

Table 10. Findings on Proposition 1

\begin{tabular}{|l|c|c|}
\hline Proposition: Enablers & Research Findings & Conclusions \\
\hline Perceived Usefulness & $\begin{array}{c}\text { Factor 1: } \\
\text { Perceived Utility }\end{array}$ & $\begin{array}{c}\text { Effectively found - } \\
\text { combination of two constructs }\end{array}$ \\
\hline Perceived Ease of Use & $\begin{array}{c}\text { Factor 1: } \\
\text { Perceived Utility } \\
\text { Trust }\end{array}$ & $\begin{array}{c}\text { Fffectively found - } \\
\text { combination of two constructs }\end{array}$ \\
\hline Self-efficacy & Found \\
\hline Economic Benefice Trust & $\begin{array}{c}\text { Factor 2: Socio- } \\
\text { Economic Influencers }\end{array}$ & $\begin{array}{c}\text { Effectively found - } \\
\text { combination of two constructs }\end{array}$ \\
\hline Social Influence & $\begin{array}{c}\text { Factor 2: Socio- } \\
\text { Economic Influencers }\end{array}$ & $\begin{array}{c}\text { Effectively found - } \\
\text { combination of two constructs }\end{array}$ \\
\hline $\begin{array}{l}\text { Enjoyment /Innovation } \\
\text { /Rarity }\end{array}$ & Not found \\
\hline N.A. & Factor 6: Youth & New factor \\
\hline Results: Proposition 1 is partially supported \\
\hline
\end{tabular}


Table 10 indicates that five of the original enabling factors from Proposition 1 were found, two original factors were not found, and one new enabling factor was identified. Therefore, Proposition 1 is partially supported.

"Perceived Usefulness" was effectively found in combination with "perceived ease of use" to form the enabling factor, Perceived Utility. South African users are thus more inclined to adopt FinTech services if it makes their lives simpler and easier, if it fulfils a specific need that they have, if it saves them time, and if it allows them to access these services when they are on-the-go. These findings support existing research (Akturan and Tezcan 2012, Dapp 2014, EY 2016, Ismail and Masinge 2011, Kim et al. 2016, Pandiya and Gupta 2015, Singh and Srivastava 2018, Wentzel et al. 2013). "Perceived Ease of Use" variables, as found in Perceived Utility, positively influence FinTech adoption in South Africa if users view the technology as easy to use and understand, and if it saves them time. This directly supports both local and international research (Chuang et al. 2016, Dastan and Gurler 2016, EY 2016, Pandiya and Gupta 2015, Wentzel et al. 2013).

"Trust" was also identified as an enabling factor with specific focus on data security and device trust as encapsulated by factor 5, Mobile Device Trust. This supports the findings of existing research that trust can have a positive effect on FinTech adoption (Baptista and Oliveira 2015, Hanafizadeh et al. 2014, Ismail and Masinge 2011, Kim et al. 2009, Maduku 2017, Priya et al. 2018, Singh and Srivastava 2018). As most new FinTech entrants tend to be unknown players in the market (EY 2016) the role of brand trust initially plays a secondary role in relation to the more functional trust drivers like data privacy and account security. However, the role of brand will increasingly become important as the market matures, emotive benefits come into play and consumers start making switching decisions post adoption. This needs to be studied in further detail in future research.

"Economic benefit" was effectively found as part of Factor 2, Socio-Economic Influencers. This is consistent with existing research on South African m-banking adoption (Chigada and Hirschfelder 2017, Maduku 2017) and supports the notion that FinTech adoption is positively influenced by cost savings. Existing research did not touch on loyalty programmes, but this study found reward systems to be a significant driver of adoption and therefore a possible area for future research.

"Social influence" also forms part of Factor 2, Socio-Economic Influencers. Positive word-of-mouth and peer influence have been cited as enabling forces that help with FinTech adoption (EY 2016, Wentzel et al. 2013) and this was also the case in this study's research findings.

As mentioned, two original enabling factors were not found during the study namely, "Enjoyment/Innovation/Rarity" and "Self-efficacy". The former was deemed irrelevant during the qualitative phase and the latter did not garner sufficient statistical relevance during the quantitative phase. Therefore, in contrast to existing literature on "Enjoyment/Innovation/Rarity" (Lee et al. 2003, Pikkarainen et al. 2004) and "Self-efficacy" (Alalwan et al. 2015, Koksal 2016), these factors were not deemed to be relevant in terms of FinTech adoption in the South African milieu. 
A new enabling factor was however identified, Youth. Given the results of the research findings, South Africans view the younger generation to be more open towards using FinTech and "youth" was therefore recognised as an enabling factor. Notably, "Age" did not surface as a significant factor during the literature review on FinTech adoption, but was included in the quantitative phase due to insights gathered in the preceding qualitative phase.

\section{Discussion Pertaining to Proposition 2}

Table 11 indicates that one of the original inhibiting factors from Proposition 2 was found whilst the other was effectively found. Firstly, Perceived Risk was initially identified during the literature review as an inhibitor to FinTech adoption (Dapp 2014, Koenig-Lewis et al. 2010, Wentzel et al. 2013) and subsequently supported by the research findings. Interestingly, the role of human interaction came through very strongly and is an ideal area for future research, in order to better understand how the lack of human interaction has a negative influence on South African consumers when it comes to FinTech adoption.

Table 11. Findings on Proposition 2

\begin{tabular}{|l|c|c|}
\hline Proposition: Inhibitors & Research Findings & Conclusions \\
\hline $\begin{array}{l}\text { Perceived risk and lack } \\
\text { of trust }\end{array}$ & $\begin{array}{c}\text { Factor 3: } \\
\text { Perceived Risk }\end{array}$ & Found \\
\hline Perceived Cost of Use & $\begin{array}{c}\text { Factor 4: } \\
\text { Associated Costs }\end{array}$ & $\begin{array}{c}\text { Effectively found - combination } \\
\text { of two constructs }\end{array}$ \\
\hline \multicolumn{2}{|l|}{ Results: Proposition 2 is effectively supported } \\
\hline
\end{tabular}

"Perceived cost of use" was effectively found along with internet accesses in Factor 4, associated costs. The fact that the study showed a negative relationship between FinTech adoption and perceived FinTech costs correlates with prior research (Hanafizadeh et al. 2014, Ismail and Masinge 2011, Pandiya and Gupta 2015). Respondents did not necessarily agree that they were personally deterred from adopting FinTech based on associated costs, but this is very likely due to the skewed sample demographic. In other words, it can be assumed based on the high levels of education that the research sample consisted of more affluent South African consumers who can afford to pay a premium on certain banking services. Future research should explore this further by studying a more diverse pool of South African respondents and how associated costs impact their adoption behaviour.

The additional insight that there is a lack of awareness of m-banking can be addressed by banks developing marketing campaigns to educate consumers, particularly prospective new customers.

Proposition 2 was effectively supported based on the above findings. 
Vol. 8, No. 1 Slazus \& Bick: Factors that Influence FinTech Adoption in South Africa...

\section{Recommendations}

This research provides a number of findings and recommendations in terms of the identified enabling and inhibiting factors for FinTech adoption which ultimately form the basis of an Enhancement Criteria Model. These enhancement criteria can be used by new and existing FinTechs to improve their businesses models and to be more aligned to South African consumer perspectives. This Enhancement Criteria Model encapsulates an external and internal environment, consisting of the following components given in Figure 2.

The Enhancement Criteria Model identifies two main components from the External Environment that influence both potential and existing users namely, demographics \& psychographics and social influence.

\section{Demographics and Psychographics}

Demographics and psychographics each play a major role in shaping consumer behaviour. Firstly, it is recommended to segment audiences based on age profile. An inverse relationship was found between seniority and youth; older people tend to be more reluctant to use mobile devices. Secondly, it is important to understand users' attitudes towards human-interaction when dealing with FinTech services. Early adopters, who predominantly fall into the Millennial 20-35 year old age group, are typically more comfortable with a completely digitised experience.

Figure 2. Enhancement Criteria Model for New and Existing FinTech Providers

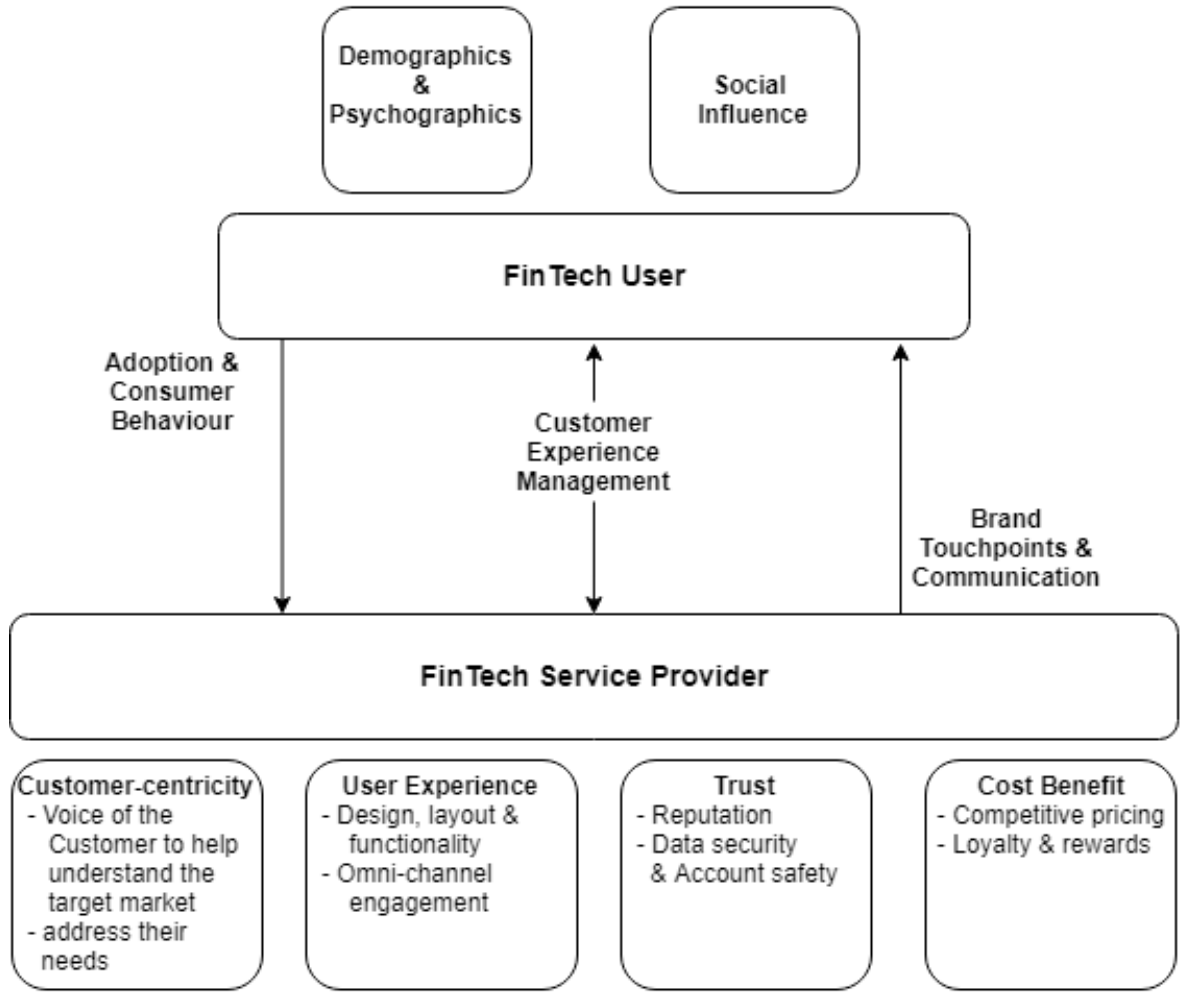

Source: Derived from this study. 


\section{Social Influence}

FinTech providers should be aware of the persuasive role that social influence plays in FinTech adoption. It was found that reputable community members, family and friends all impact users' intention to use FinTech services/products. Therefore, businesses should treat existing customers as direct marketing and referral sources that have the potential to generate commercial value through positive word-of-mouth. Marketing departments should be focused on creating community brand ambassadors that will help forge authentic and trusted relationship with users at grassroots level.

The Enhancement Criteria Model focuses on four main components of the Internal Environment that are of utmost importance and should be addressed by new entrants and established FinTechs alike:

\section{Customer-Centricity}

It is essential for FinTechs to adopt a customer-centric and not a productcentric business philosophy. Global business consultancy, Ernst \& Young stresses the importance of customer-centricity by stating that "having a clear understanding of customer needs and behaviours across the organisation will help drive profitable growth strategies and provide the confidence to invest in opportunities at a time when staying within budget is extremely difficult" (2013, p. 1). This way of thinking has led many organisations to launch programmes that focus on understanding their ideal customer and giving this customer a proverbial seat at the boardroom table.

\section{User Experience}

User Experience (UX) is all about optimising users' interaction with your brand; this commonly pertains to the navigation of digital assets like websites and mobile apps. The research found that users highly valued "ease of use" when it came to FinTech. Therefore businesses need to ensure that they provide thoughtful interface design and clear navigation, as well as an omni-channel content strategy to facilitate user engagement, with appropriate alignment and integration.

\section{Trust}

Data security, account safety, transparency and clear communication are key components of any FinTech provider's success, especially in terms of building trust and stimulating user adoption. Given the highly regulated environments in which these FinTechs operate, trust has become a point of parity rather than being a point of differentiation. FinTechs need to ensure data security an account safety is maintained, and that they build a reputation as a trusted provider of financial services. Regulatory accreditation and social endorsement are also examples of how FinTech start-ups can to build trust in the hearts and minds of potential new customers. 
Vol. 8, No. 1 Slazus \& Bick: Factors that Influence FinTech Adoption in South Africa...

\section{Cost Benefit}

Consumers look for high utility services at competitive prices. Offering "value for money" to consumers is always a major benefit, but in the financial services industry this is not mutually exclusive to offering consumers a trusted service, i.e., consumers will consider pricing and rates, but not at the cost of trust and surety. FinTechs need to ensure that they provide competitive pricing, and should provide loyalty and reward programmes to build long-term relationships.

The interaction between FinTech providers and users is dependent on delivering consistent and on-brand messaging through all communication channels, at every brand touchpoint. Customer Experience Management (CEM) is at the heart of managing the interactions. It is a holistic approach to how the company and its offering can be relevant to a customer's life (Schmitt 2003). If executed properly, CEM will increase profitability as it relates to increased customer retention and loyalty. CEM is the proverbial golden thread that runs throughout the Enhancement Criteria Model and ties all internal and external components together.

\section{Recommendations for Future Research}

Further research could be conducted with different respondent groups. A mixed-methods study consisting of a more representative and diverse sample of respondents could be utilized. A study that focuses on FinTech rejecters and the factors that inhibit them from adopting FinTech offerings would provide further insights, as well as a study on potential switching behaviour barriers and incentives.

A quantitative, cross-generational study to measure FinTech adoption in different age profiles. This longitudinal study can analyse FinTech user migration between generations and test whether the adoption gap closes as time progresses and Millennials/Generation Y/Baby Boomers age.

A comparative brand study to test what effect trust, loyalty and referrals have on new FinTech providers' brand equity development could be applied. It would be interesting to compare consumer confidence levels and user adoption between a start-up FinTech and an incumbent financial institution.

\section{References}

Adams J, Khan HTA, Raeside R, White DI (2007) Research methods for graduate business and social science students. New Delhi: SAGE Publications.

Akhlaq A, Ahmed E (2013) The effect of motivation on trust in the acceptance of internet banking in a low income country. International Journal of Bank Marketing 31(2): $115-125$.

Akturan U, Tezcan N (2012) Mobile banking adoption of the youth market: perceptions and intentions. Marketing Intelligence and Planning 30(4): 444-459. 
Alalwan A, Dwivedi Y, Rana N, Lal B, Williams M (2015) Consumer adoption of Internet banking in Jordan: examining the role of hedonic motivation, habit, self-efficacy and trust. Journal of Financial Services Marketing 20(2): 145-157.

Bagozzi RP (2007) The legacy of the technology acceptance model and a proposal for a paradigm shift. Journal of the Association for Information Systems 8(4): 244-254.

Bank Zero (2018) Bank Zero homepage. Retrieved from: https:// www.bankzero.co.za/. [Accessed 10 December 2019]

Bankole O, Cloete E (2011) Mobile banking: a comparative study of South Africa and Nigeria. In IEEE Africon. Livingstone, Zambia: IEEE.

Baptista G, Oliveira T (2015) Understanding mobile banking: the unified theory of acceptance and use of technology combined with cultural moderators. Computers in Human Behavior 50(Sep): 418-430.

Basel Committee on Banking Supervision (2018) Sound practices: implications of fintech developments for banks and bank supervisors. Basel: Switzerland: Basel Committee on Banking Supervision.

Bertha Centre (2016) Financial inclusion hackathon. Cape Town, SA: Bertha Centre.

Bryman A, Bell E (2011) Business research methods. Oxford: Oxford University Press.

Chigada JM, Hirschfelder B (2017) Mobile banking in South Africa: a review and directions for future research. SA Journal of Information Management 19(1): 1-9.

Chitungo S, Munongo S (2013) Extending the Technology acceptance model to mobile banking adoption in rural Zimbabwe. Journal of Business Administration and Education 3(1): 51-79.

Chuang L-M, Liu C-C, Kao H-K (2016) The adoption of fintech service: TAM perspective. International Journal of Management and Administrative Sciences (IJMAS) 3(07): 2225-722501.

Cronbach LJ (1951) Coefficient alpha and the internal structure of tests. Psychometrika 16(3): 297-334.

Cruz P, Neto LBF, Muñoz-Gallego P, Laukkanen T (2010) Mobile banking rollout in emerging markets: Evidence from Brazil. International Journal of Bank Marketing 28(5): 342-371.

Dapp T (2014) Fintech - The digital (r)evolution in the financial sector. Frankfurt am Main, Germany: DB Research.

Dastan I, Gurler C (2016) Factors affecting the adoption of mobile payment systems: an empirical analysis. EMAJ: Emerging Markets Journal 6(1): 1-16.

Davis FD (1985) A technology acceptance model for empirically testing new end-user information systems: theory and results. Boston, MA: Kent Publications Co.

Davis FD, Bagozzi R, Warshaw P (1986) User Acceptance of computer technology: a comparison of two theoretical models. Massachusetts, USA: Massachusetts Institute of Technology.

Demirguc-Kunt A, Klapper L, Singer D, Ansar S, Hess J (2017) The global findex database: measuring financial inclusion and the fintech revolution. Washington DC, USA.

Dhar V, Stein RM (2017) FinTech platforms and strategy. Communications of the ACM 60(10): 32-35.

Ernst \& Young - EY (2013) The journey toward greater customer centricity. Ernst \& Young.

Ernst \& Young - EY (2016) EY FinTech adoption index, 1-44. Ernst \& Young.

Financial Stability Board (2017) Financial stability implications from fintech: supervisory and regulatory issues that merit authorities' attention (June), 65. Financial Stability Board. 
Gangwal N, Bansal V (2016) Application of decomposed theory of planned behavior for m-commerce adoption in India. In Proceedings of the $18^{\text {th }}$ International Conference on Enterprise Information Systems, (April), 357-367.

Gomber P, Kauffman RJ, Parker C, Weber BW (2018) On the Fintech revolution: interpreting the forces of innovation, disruption, and transformation in financial services. Journal of Management Information Systems 35(1): 220-265.

Gulamhuseinwala I, Bull T, Lewis S (2015) FinTech is gaining traction and young, highincome users are the early adopters. The Journal of Financial Perspectives 3(3): 117.

Hair J, Black W, Babin B, Anderson R (2010) Multivariate data analysis. $7^{\text {th }}$ Edition. Upper Saddle River NJ: Pearson.

Hanafizadeh P, Behboudi M, Koshksaray A, Tabar M (2014) Mobile-banking adoption by Iranian bank clients. Telematics and Informatics 31(1): 62-78.

Ismail T, Masinge K (2011) Working paper series mobile banking: innovation for the poor. Research and Training Support to Build African Capacity in Science, Technology, and Innovation Indicators No. 2001-074. Pretoria, South Africa.

Karjaluoto H, Mattila M, Pento T (2002) Factors underlying attitude formation towards online banking in Finland. International Journal of Bank Marketing 20(6): 261-272.

Kemp S (2018) Digital in 2018 in Southern Africa. Retrieved from: https:// hootsuite.com/ resources/digital-in-2018-emea. [Accessed 9 June 2018]

Kim G, Shin B, Lee HG (2009) Understanding dynamics between initial trust and usage intentions of mobile banking. Information Systems Journal 19(3): 283-311.

Kim Y, Choi J, Park, Y-J, Yeon JL (2016) The adoption of mobile payment services for "fintech." International Journal of Applied Engineering Research 11(2): 1058-1061.

Koenig-Lewis N, Palmer A, Moll A (2010) Predicting young consumers' take up of mobile banking services. International Journal of Bank Marketing 28(5): 410-432.

Koksal MH (2016) The intentions of Lebanese consumers to adopt mobile banking. International Journal of Bank Marketing 34(3): 327-346.

Lee MSY, McGoldrick PJ, Keeling KA, Doherty J (2003) Using ZMET to explore barriers to the adoption of $3 \mathrm{G}$ mobile banking services. International Journal of Retail \& Distribution Management 31(6): 340-348.

Leung CMT, Keating JP, Salkind ENJ (2010) Encyclopedia of research design. Edited by NJ Salkind. United States: SAGE Publications.

Maduku DK (2017) Customer acceptance of mobile banking. Social Behavior and Personality 45(6): 893-900.

Makanyeza C (2017) Determinants of consumers' intention to adopt mobile banking services in Zimbabwe. International Journal of Bank Marketing 35(6): 997-1017.

Pandiya S, Gupta S (2015) A study of changing pattern and demand for mobile banking services in India. Global Journal of Enterprise Information System 7(1): 16-27.

Pett M, Lackey N, Sullivan J (2003) Making sense of factor analysis: the use of factor analysis for instrument development in health care research. $6^{\text {th }}$ Edition. SAGE Publications.

Pikkarainen T, Pikkarainen K, Karjaluoto H, Pahnila S (2004) Consumer acceptance of online banking: An extension of the technology acceptance model. Internet Research 14(3): 224-235.

Priya R, Gandhi AV, Shaikh A (2018) Mobile banking adoption in an emerging economy. Benchmarking: An International Journal 25(2): 743-762.

Püschel J, Mazzon JA, Hernandez JMC (2010) Mobile banking: proposition of an integrated adoption intention framework. International Journal of Bank Marketing 28(5): 389-409. 
Rogers EM (2005) Diffusion of innovations. $5^{\text {th }}$ Edition. New York, NY: Macmillian Publishing Co.

Schmitt B (2003) Customer experience management: a revolutionary approach to connecting with your customers. Hoboken, New Jersey: John Wiley \& Sons, Inc.

Shaikh AA, Karjaluoto H (2014) Mobile banking adoption: a literature review. Telematics and Informatics 32(1): 129-142.

Singh S, Srivastava RK (2018) Predicting the intention to use mobile banking in India. International Journal of Bank Marketing 36(2): 357-378.

Venkatesh V, Morris MG, Davis GB, Davis FD (2003) User acceptance of information technology: toward a unified view. Source: MIS Quarterly 27(3) 425-478.

Wang Y-S, Lin H-H, Luarn P (2006) Predicting consumer intention to use mobile service. Information Systems Journal 16(2): 157-179.

Wentzel JP, Diatha KS, Yadavalli V (2013) An application of the extended technology acceptance model in understanding technology-enabled financial service adoption in South Africa. Development Southern Africa 30(4-05): 659-673.

Zhou T (2011) An empirical examination of initial trust in mobile banking. Internet Research 21(5): 527-540.

Zikmund WG, Babin BJ, Carr JC, Griffin M (2012) Business research methods. $9^{\text {th }}$ Edition. Andover, UK: Cengage Learning. 
